From the Department of Child Health, Medical School University of Pajajaran/ Hasan Sadikin General Hospital, Bandung.

\title{
Percentiles for Height and Weight of Children between 6-14 Years of Age in Bandung.
}

by

\author{
HENDRA PERMADHI, DOERIAT DANOEMOELIA, HARTAMAN \\ TJOKROHUSADA and SUGIRI.
}

\begin{abstract}
From a cross sectional study on height and weight of children from 6 to 14 years of age, percentile curves were drawn. This study was done in Bandung during a period of 10 months in 1973. The subjects were obtained from 215 elementary schools and 17 Kindergartens and 65,809 pupils were measured. Only 15,099 children were selected for this study based on their birthdates. The 10th, 30th, 50th, 70th and 90th percentiles, mean and standard deviations were calculated and plotted in graphs. Data within the range + and $-2 S D$ were considered normal. Data in the category between $+2 S D$ and 90th percentile were considered "Tall or heavy", between 30 th and 70 th percentiles "Average,, and between 10th percentile and -2 SD "Short or light". Data outside the limits of $\pm 2 S D$ were considered extremes. These graphs can be recommended in following the growth of children transversally as well as longitudinally.
\end{abstract}

Received 20th Marçh 1976. 
The following median for height and weight has been achieved:

\begin{tabular}{|c|c|r|r|r|r}
\hline Age (years) & \multicolumn{1}{|c|}{6} & \multicolumn{1}{c|}{8} & 10 & 12 & \multicolumn{1}{c}{14} \\
\hline Weight of boys (kg) & 17.71 & 19.53 & 23.23 & 27.09 & 32.39 \\
Weight of girls (kg) & 17.72 & 19.56 & 23.71 & 29.14 & 36.14 \\
Height of boys (cm) & 108.62 & 116.33 & 124.27 & 132.07 & 139.82 \\
Height of girls (cm) & 108.34 & 115.58 & 125.11 & 135.25 & 143.54 \\
\hline
\end{tabular}

Boys at the age of 6 to 8 years were taller and heavier than girls, while after 8 years of age the contrary uas true. The annual increments of height for boys from 6 to 14 years were approximately 4 and for girls $4.5 \mathrm{~cm}$.. The annual increments of weight for boys from 6 to 11 years were less than $2 \mathrm{~kg}$ and from 11 to 14 years were more than $2 \mathrm{~kg}$, while for girls from 6 to 9 years were less than $2 \mathrm{~kg}$ and from 9 to 14 years were more than $2 \mathrm{~kg}$.

Compared with the American standard the 90th and 50th percentiles of height and weight of children in this study were respectively far below the 50th and 10th percentiles of the American standard.

In respect to the possibility of secular shift, it is suggested to do such study periodically, at least every 10 years.

\section{Introduction}

Survey on height and weight measurements of children is seldom done in Indonesia either before or after World War II. This kind of study in Indonesia has been carried out by Zakaria (1956) and Klerks (1956).

Meredith (1962) in his study among children in USA found that girls of 1960 were taller by approximately $10 \mathrm{~cm}$. and heavier by more than $10 \mathrm{~kg}$. as com pared with those in 1880 . Studies in the Netherlands conducted by Wieringen et ai. (1968) in 1955 and 1965 revealed that a secular shift had occurred in children of elementary schools which amounted to about $2 \mathrm{~cm}$. in length and $1 \frac{1}{2} \mathrm{~kg}$. in weight.

This study has been done in 10 months from March until December 1973. A preliminary study was carried out by Hartaman et al. (1971).

The city of Bandung has approximately $1,169,606$ inhabitants, among whom are 317,782 children $(27.1 \%)$ of the age groups of $5-14$ years. There are 523 elementary schools either state or private. Each school has a complete list of pupils with dates of birth according to their birth certificates.

The purpose of this study is to establish percentile curves of body heigh and weight of school children between $6-14$ years of age and to provide each child with a personal chart in order to be able to record his growth in height and weight. These percentile curves are not only important for the evaluation of body height transversally but longitudinally as well.

\section{Material and methods}

The subjects studied consisted of 65,809 pupils from 215 elementary schools and 17 Kindergartens. Those with physical defect were excluded and only those having their birthday within one month before or after the day of measurement or six months later were included, leaving only 15,099 children for this study. By this criterion we could count the years in full or halves.

The schools were chosen at random in order to be able to complete the total number of 500 children for each age group.

The measurements were taken only once, in the morning, noon or afternoon, depending upon the time schedule of the concerning schools, by 3 nurses who were trained beforehand. To minimize the possibility of errors, the children were measured by the same nurse, supervised by the second and the registration was done by the third.

To measure the bodyweight a beam scale was used which was sealed by the Department of Mathematics of the Technological Institute in Bandung. Every morning the scale was rechecked. The child was weighted barefooted, standing cn the centre of the platform of the scale with both hands hanging freely and wearing minimal clothes. Reading was done to 100 grams accuracy.

To determine height, a metric measurer with an iron sliding headpiece fixed 
at the beam scale was used. The subject stood barefooted on the platform of the scale, facing forward with the measurer bchind him, the ends of the heels in close contact with the rear edge of the platform and opened ventrally $45^{\circ}$. Care was taken to adjust the head to get the Frankfurter line horizontally. Reading was done to $1 / 2 \mathrm{~cm}$. accuracy.

The procedure of calculating percentiles, for example to obtain the 30th percentile for weight of 8-year-old boys (See table 1) was done as follows :

a) The data were tabulated in a frequency distribution using $1 \mathrm{~kg}$. inter-

$$
P_{30}=17.99 \mathrm{~kg} .+\frac{183.9-151}{98} \times 1 \mathrm{~kg} .=18.325 \mathrm{~kg} .
$$

TABLE 1: Frequency distribution of 8-year-old boys.

\begin{tabular}{|r|c|c|c|}
\hline No. & Class interval (kg) & Frequency & $\begin{array}{c}\text { Cumulative } \\
\text { frequency }\end{array}$ \\
\hline 1 & $14.00-14.99$ & 3 & 3 \\
2 & $15.00-15.99$ & 18 & 21 \\
3 & $16.00-16.99$ & 44 & 65 \\
4 & $17.00-17.99$ & 86 & 151 \\
5 & $18.00-18.99$ & 98 & 249 \\
6 & $19.00-19.99$ & 107 & 356 \\
7 & $20.00-20.99$ & 105 & 461 \\
8 & $21.00-21.99$ & 60 & 521 \\
9 & $22.00-22.99$ & 37 & 558 \\
10 & $23.00-23.99$ & 24 & 582 \\
11 & $24.00-24.99$ & 11 & 593 \\
12 & $25.00-25.99$ & 9 & 602 \\
13 & $26.00-26.99$ & 5 & 607 \\
14 & $27.00-27.99$ & 2 & 609 \\
15 & $28.00-28.99$ & 1 & 610 \\
16 & $29.00-29.99$ & 2 & 612 \\
17 & $30.00-30.99$ & 1 & 613 \\
\hline
\end{tabular}

From the calculated percentiles, curves were drawn by way of free hand method. The data points were connected to each other in such a way as to form a smooth curve with the least possible deviation from the calculated data (In graph 1 and 2 the data points are still shown).

The mean and standard deviation were calculated as follows:

$\mathrm{M}($ mean $)=\frac{\mathrm{Efx}}{\mathrm{Ef}}$

SD (standard deviation) $=$$$
(\mathrm{Efx})^{2}
$$

$\mathrm{Efx}^{2}-\frac{}{\mathrm{Ef}}$

Ef -1

$\mathrm{E}=\operatorname{sigma}=$ number

TABLE 2: Age distribution of children included in the study.

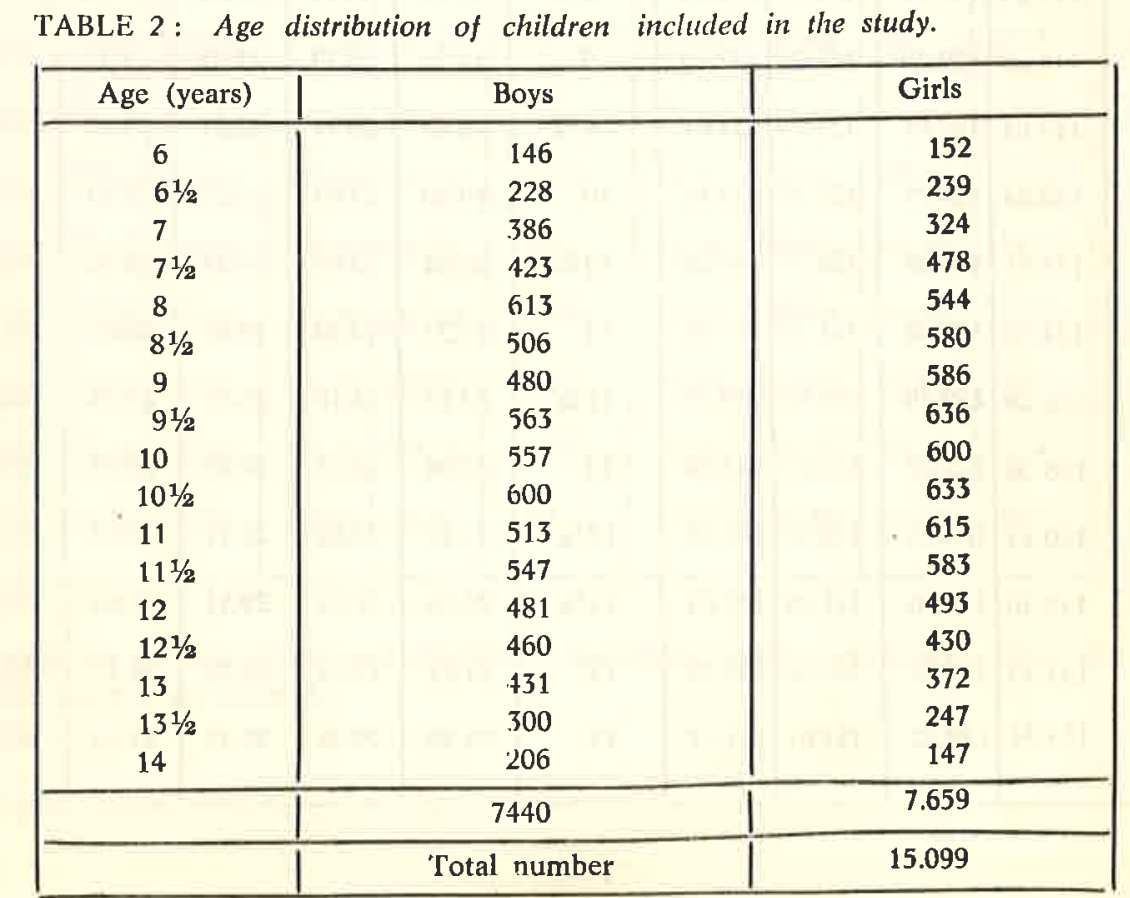

$\mathrm{x}=$ median$$
\text { TA }
$$

$\mathrm{f}=$ frequency

Anrual increments of height and weight were calculated as follows, for cxample to calculate the increment of height of boys at 7 years of age.

The mean height at 6 years was 109.39 $\mathrm{cm}$ and at 8 was $116.47 \mathrm{~cm}$ so the annual increment at 7 years of age $=$ 116.47 - 109.39

2
Results

There were 65,809 children measured but in accordance to their birthdates only 15,099 children were included in the study. Age distribution is shown in table 2 . of whom the lightest was $14 \mathrm{~kg}$. and ber of class intervals $30.700 \mathrm{~kg}$. The 183.9. In the next interval there 
From the data collected, the 10th, 30th, 50th, 70th and 90th percentiles were calculated. The results of the calculation for boys are shown in table 3 and for girls in table 4 . From these percentiles graphs were drawn, for boys in graph 1 and for girls in graph 2.
TABLE 3: Percentiles for height and weight, boys.

\begin{tabular}{|c|c|c|c|c|c|c|c|c|c|c|}
\hline \multicolumn{5}{|c|}{ HE I G H T (cm) } & \multirow{2}{*}{ Years } & \multicolumn{5}{|c|}{ W E I G H $\mathrm{T}$ (kg) } \\
\hline P 10 & P 30 & P 50 & P 70 & P 90 & & P 10 & P 30 & P 50 & P 70 & P 90 \\
\hline 104.52 & 106.50 & 108.62 & 111.38 & 115.12 & 6 & 15.15 & 16.58 & 17.71 & 18.83 & 20.63 \\
\hline 104.29 & 107.98 & 110.62 & 113.47 & 117.14 & $6^{1 / 2}$ & 15.50 & 17.06 & 17.98 & 19.11 & 20.86 \\
\hline 106.34 & 109.83 & 112.80 & 115.77 & 119.46 & 7 & 16.05 & 17.49 & 18.50 & 19.61 & 21.46 \\
\hline 107.99 & 111.60 & 114.27 & 117.37 & 121.51 & $71 / 2$ & 16.67 & 17.97 & 19.30 & 20.53 & 22.31 \\
\hline 109.28 & 113.29 & 116.33 & 119.10 & 123.77 & 8 & 16.91 & 18.33 & 19.53 & 20.69 & 22.92 \\
\hline 111.60 & 115.69 & 118.14 & 121.45 & 125.62 & $8 \frac{1}{2}$ & 17.73 & 19.44 & 20.85 & 22.21 & 24.57 \\
\hline 113.18 & 117.68 & 120.09 & 123.08 & 127.70 & 9 & 18.56 & 20.79 & 21.97 & 23.32 & 25.96 \\
\hline 114.44 & 119.01 & 122.03 & 125.03 & 131.01 & $91 / 2$ & 18.98 & 20.77 & 22.21 & 23.82 & 26.69 \\
\hline 116.16 & 120.84 & 124.27 & 127.49 & 13216 & 10 & 19.70 & 2167 & 23.23 & 24.94 & 27.34 \\
\hline 118.52 & 123.51 & 126.68 & 130.25 & 135.28 & $10^{1 / 2}$ & 20.64 & 22.87 & 24.34 & 26.16 & 29.14 \\
\hline 119.88 & 124.58 & 127.98 & 131.32 & 137.97 & 11 & 21.27 & 23.20 & 24.91 & 26.97 & 30.37 \\
\hline 121.97 & 126.48 & 129.79 & 133.62 & 139.45 & $11^{1 / 2}$ & 22.12 & 24.16 & 25.91 & 27.94 & 32.00 \\
\hline 124.05 & 128.50 & 132.07 & 135.81 & 142.28 & 12 & 22.94 & 25.31 & 27.09 & 29.29 & 32.94 \\
\hline 124.66 & 130.45 & 134.75 & 138.52 & 145.49 & $12 \frac{1}{2}$ & 23.37 & 25.80 & 28.11 & 30.53 & 35.55 \\
\hline 126.67 & 132.50 & 136.40 & 141.09 & 147.05 & $13^{1 / 2}$ & 24.76 & 27.35 & 29.51 & 32.69 & 37.67 \\
\hline 127.16 & 133.49 & 137.87 & 142.58 & 150.19 & 13 & 24.84 & 27.44 & 30.76 & 34.17 & 41.58 \\
\hline 128.36 & 134.84 & 139.82 & 144.01 & 151.17 & 14 & 25.59 & 29.36 & 32.39 & 35.50 & 42.47 \\
\hline
\end{tabular}

TABLE 4: Percentile for height and weight, girls.

\begin{tabular}{|c|c|c|c|c|c|c|c|c|c|c|}
\hline \multicolumn{5}{|c|}{ H E I G H T $(\mathrm{cm})$} & \multirow{2}{*}{ Years } & \multicolumn{5}{|c|}{ W E I G H T (kg) } \\
\hline P 10 & P 30 & P 50 & P 70 & P 90 & & P 10 & P 30 & P 50 & P 70 & P 90 \\
\hline 102.14 & 105.82 & 108.34 & 110.63 & 115.36 & 6 & 14.77 & 16.22 & 17.02 & 17.86 & 20.39 \\
\hline 104.36 & 107.12 & 109.38 & 112.08 & 117.41 & $61 / 2$ & 15.32 & 16.50 & 17.57 & 18.55 & 20.46 \\
\hline 105.02 & 108.50 & 112.41 & 115.38 & 119.92 & 7 & 15.97 & 17.31 & 18.28 & 19.75 & 21.87 \\
\hline 106.78 & 110.78 & 113.31 & 116.21 & 120.60 & $7 \frac{1 / 2}{1 / 2}$ & 16.43 & 17.76 & 18.89 & 20.13 & 22.13 \\
\hline 109.09 & 113.08 & 115.50 & 118.76 & 123.92 & 8 & 16.81 & 18.40 & 19.56 & 20.97 & 23.30 \\
\hline 110.90 & 115.45 & 118.36 & 121.56 & 126.23 & $81 / 2$ & 17.67 & 19.37 & 20.59 & 22.00 & 24.60 \\
\hline 112.74 & 116.94 & 120.24 & 123.78 & 129.24 & 9 & 18.40 & 20.20 & 21.60 & 23.02 & 25.87 \\
\hline 114.35 & 118.79 & 122.34 & 125.29 & 130.33 & $9^{1 / 2}$ & 18.84 & 20.67 & 22.08 & 23.66 & 26.73 \\
\hline 117.46 & 121.69 & 125.11 & 128.46 & 134.43 & 10 & 20.06 & 21.99 & 23.71 & 25.59 & 28.77 \\
\hline 118.81 & 123.45 & 127.03 & 130.89 & 136.48 & $101 / 2$ & 20.69 & 22.66 & 24.71 & 26.44 & 30.55 \\
\hline 121.20 & 126.16 & 129.74 & 134.04 & 140.69 & 11 & 21.60 & 24.13 & 25.85 & 28.11 & 32.13 \\
\hline 123.78 & 129.43 & 133.24 & 137.13 & 143.78 & $11^{1 / 2}$ & 22.57 & 25.31 & 27.72 & 30.58 & 35.60 \\
\hline 126.04 & 130.89 & 135.25 & 139.86 & 144.84 & 12 & 23.75 & 26.72 & 29.14 & 32.19 & 37.58 \\
\hline 127.00 & 133.58 & 138.06 & 141.84 & 147.50 & $12^{1 / 2}$ & 24.42 & 27.89 & 30.96 & 33.79 & 39.30 \\
\hline 130.19 & 135.82 & 140.07 & 143.59 & 148.63 & 13 & 25.68 & 29.66 & 32.69 & 36.03 & 40.84 \\
\hline 131.39 & 136.68 & 140.80 & 144.54 & 149.14 & $13^{1 / 2}$ & 26.86 & 30.53 & 34.11 & 37.79 & 43.45 \\
\hline 133.49 & 139.16 & 143.54 & 147.87 & 152.97 & 14 & 27.73 & 32.88 & 36.14 & 39.47 & 44.71 \\
\hline
\end{tabular}

In addition to this, mean and standard deviation were calculated and the results are shown in table 5 . 
TABLE 5: Mean and standard deviation for height and weight.

\begin{tabular}{|c|c|c|c|c|c|c|c|c|}
\hline \multicolumn{4}{|c|}{ BOY S } & \multirow{3}{*}{$\begin{array}{l}\text { Age } \\
\text { Years }\end{array}$} & \multicolumn{4}{|c|}{ G I R L S } \\
\hline \multicolumn{2}{|c|}{ HEIGHT } & \multicolumn{2}{|c|}{ WEIGHT } & & \multicolumn{2}{|c|}{ HEIGHT } & \multicolumn{2}{|c|}{ WEIGHT } \\
\hline Mean & S.D. & Mean & S.D. & & Mean & S.D. & Mean & S.D. \\
\hline 109.37 & 4.84 & 17.94 & 2.14 & 6 & 108.61 & 5.18 & 17.35 & 2.15 \\
\hline 110.97 & 5.08 & 18.18 & 2.07 & $61 / 2$ & 110.03 & 5.24 & 17.82 & 2.27 \\
\hline 112.81 & 5.08 & 18.73 & 2.18 & 7 & 112.47 & 5.44 & 18.68 & 2.30 \\
\hline 114.59 & 5.17 & 19.57 & 3.27 & $71 / 2$ & 113.60 & 5.24 & 19.20 & 2.56 \\
\hline 116.47 & 6.41 & 19.70 & 2.57 & 8 & 116.17 & 5.77 & 19.95 & 2.79 \\
\hline 118.55 & 5.73 & 21.05 & 2.90 & $8 \frac{1}{2}$ & 118.61 & 6.15 & 20.98 & 2.89 \\
\hline 120.45 & 5.82 & 22.06 & 3.70 & 9 & 120.62 & 6.33 & 21.86 & 2.89 \\
\hline 122.34 & 6.54 & 22.66 & 3.42 & $91 / 2$ & 122.28 & 6.24 & 22.56 & 3.45 \\
\hline 124.25 & 6.60 & 23.44 & 3.12 & 10 & 125.55 & 6.64 & 24.20 & 3.74 \\
\hline 126.90 & 6.91 & 24.78 & 3.63 & $10^{1 / 2}$ & 127.43 & 6.95 & 25.05 & 3.99 \\
\hline 128.51 & 7.17 & 25.51 & 4.79 & 11 & 130.34 & 7.54 & 26.41 & 4.95 \\
\hline 130.42 & 6.83 & 26.59 & 4.19 & $11^{1 / 2}$ & 133.46 & 7.71 & 28.35 & 5.63 \\
\hline 132.58 & 7.19 & 27.72 & 4.31 & 12 & 135.43 & 7.41 & 29.91 & 5.28 \\
\hline 134.82 & 7.97 & 28.76 & 5.57 & $12 \frac{1}{2}$ & 137.66 & 8.19 & 31.44 & 5.91 \\
\hline 136.85 & 7.85 & 30.54 & 5.30 & 13 & 139.62 & 7.10 & 33.09 & 5.73 \\
\hline 138.58 & 9.26 & 31.77 & 6.25 & $131 / 2$ & 140.18 & 7.70 & 34.50 & 6.47 \\
\hline 139.85 & 8.98 & 33.01 & 6.06 & 14 & 143.19 & 8.34 & 36.62 & 6.61 \\
\hline
\end{tabular}

Comparison between mean, standard deviation and percentiles are shown for

and "Short or light", for boys in graph 5 and for girls in graph 6.

Annual increments of height are

shown in table 6 and drawn for height in graph 7 and for weight in graph 8 .

TABLE 6: Annual increments for height and weight.

\begin{tabular}{|c|c|c|c|c|}
\hline \multirow{2}{*}{ AGE } & \multicolumn{2}{|c|}{ B O Y S } & \multicolumn{2}{|c|}{ G I R L S } \\
\hline & $\begin{array}{l}\text { Height } \\
\text { (cm) }\end{array}$ & $\begin{array}{c}\text { Weight } \\
(\mathrm{kg})\end{array}$ & $\begin{array}{l}\text { Height } \\
(\mathrm{cm})\end{array}$ & $\begin{array}{c}\text { Weight } \\
(\mathrm{kg})\end{array}$ \\
\hline 6 & & & & \\
\hline 7 & 3.55 & 0.88 & 3.78 & 1.30 \\
\hline 8 & 3.82 & 1.67 & 4.08 & 1.59 \\
\hline 9 & 3.89 & 1.87 & 4.67 & 2.13 \\
\hline 10 & 4.03 & 1.73 & 4.86 & 2.28 \\
\hline 11 & 4.17 & 2.14 & 4.94 & 2.86 \\
\hline 12 & 4.17 & 2.52 & 4.64 & 3.34 \\
\hline 13 & 3.64 & 2.65 & 3.88 & 3.36 \\
\hline 14 & & & & \\
\hline
\end{tabular}

\section{Discussion}

This cross sectional study processed the results of measurement on height and weight of 15,099 children from 215 elementary schools and 17 Kindergartens. The aim to include 500 children in each age group was not met for the age groups
6-7 and 13-14 years (Table 2). The reason for this was that the number of Kindergartens included in this study was too small while most of the children of the age group 13-14 years have passed the elementary school. As the data for these age groups were considered inade- 
quate, the percentile curves for these age groups were plotted as interrupted lines.

In this study children in the 90th percentile or above were considered "Tall or heavy", the middle $40 \%$ "Average" and those in the 10th percentile or below "Short or light" according to Meredith and Knott (1963). Data within the range of $t$ and -2 Standard deviations were considered normal, while those outside this range were considered extremes according to Gunther (1927) and Huth (1926).

Graphs 3 and 4 show that the mean curves are a little above the median curves, which is in accordance with studies in the Netherlands (Van Wieringen, 1968). This was probably because most of the data distributed were skewed to the right, which means that there were short or light children than tall or heavy ones.

Graph 7 and 8 show increments for height and weight which were calculated from the average of two-yearly increments. Studies in other countries used intervals of $1 / 2$ or 1 year. This was not done in this study because the ranges of the data were too wide and gave unsatisfactory results. The reason for this might be due to the great socio-economical fluctuations in the local society. This could probably be avoided by in creasing the number of the subjects. The annual increments of height for boys and girls at the ages of 6-14 years were about 4 and $4.5 \mathrm{~cm}$. respectively. The annual increments of weight for boys at the ages of 6-11 years were less than $2 \mathrm{~kg}$. and above this age more than $2 \mathrm{~kg}$, while an increment of more than $2 \mathrm{~kg}$. was reached by girls at about 10 years of agc. The curves for weight increments show growth spurt; for boys and girls respectively at the age of 10 and 9 years. This is about in accordance with studies in the Netherlands (Van Wieringen, 1968) which showed growth spurts of weight for girls at the age of 9.5 and for boys at 10 years.

Comparisons of the mean values for both sexes are shown in table 5 . The mean height for boys at the ages of 6 and 8 years was respectively 0.76 and $0.30 \mathrm{~cm}$. more than girls, on the contrary at the ages of 10,12 and 14 years girls were respectively $1.30,2.85$ and 3.34 $\mathrm{cm}$. liigher than boys. Boys at the age of 6 years were $0.59 \mathrm{~kg}$. heavier than girls. On the contrary at the ages of $8,10,12$ and 14 years, girls were respectively $0.25,0.76$, 2.19 and $3.61 \mathrm{~kg}$. heavier than boys. In general, boys at the ages of $6-$ 8 years were a little taller and hea. vier than girls, but above this age the opposite was true. Data from the $\mathrm{Ne}$ therlands showed that the boys at the ages of 6-11 years were taller and heavier than girls and at the ages of 11-14 years the opposite was true.

Median values from other countries such as USA (Nelson, W.E.: Textbook of Pediatrics, 9th Ed. 1969), Netherlands (Van Wieringen, 1968), England (Tanner, 1965) and India (Gopalan, 1971) are shown in tables 7, 8, 9 and 10. American and Dutch children had about the
TABLE 7: Height of boys from different countries

\begin{tabular}{|c|c|c|c|c|c|c|}
\hline Country & $\begin{array}{l}\text { Present } \\
\text { study }\end{array}$ & India & England & $\begin{array}{l}\text { Nether- } \\
\text { lands }\end{array}$ & \multicolumn{2}{|c|}{$\begin{array}{c}\text { United States of } \\
\text { America }\end{array}$} \\
\hline Year & 1973 & 1968 & 1965 & 1965 & \multicolumn{2}{|c|}{ Nelson 9th Ed. 1969} \\
\hline Percentile & P 50 & P 50 & P 50 & P 50 & P 10 & P 50 \\
\hline $6 \mathrm{yr}$. & 108.62 & 108.5 & 114.6 & 117.8 & 111.2 & 117.5 \\
\hline $7 \mathrm{yr}$. & 112.80 & 113.9 & 120.5 & 123.8 & 116.9 & 124.1 \\
\hline $8 \mathrm{yr}$. & 116.33 & 119.3 & 126.2 & 129.6 & 123.1 & 130.0 \\
\hline $9 \mathrm{yr}$. & 120.09 & 123.7 & 131.6 & 134.8 & 128.3 & 135.5 \\
\hline $10 \mathrm{yr}$. & 124.27 & 128.4 & 136.8 & 139.8 & 132.8 & 140.3 \\
\hline $11 \mathrm{yr}$, & 127.98 & 133.4 & 141.9 & 144.6 & 137.3 & 144.2 \\
\hline $12 \mathrm{yr}$. & 132.07 & 138.3 & 147.3 & 149.6 & 142.4 & 149.6 \\
\hline $13 \mathrm{yr}^{\circ}$ & 136.40 & 144.6 & 153.4 & 155.1 & 146.6 & 155.0 \\
\hline $14 \mathrm{yr}$. & 139.82 & 150.1 & 160.7 & 161.3 & 152.1 & 162.7 \\
\hline
\end{tabular}

TABLE 8: Weight of boys from different countries

\begin{tabular}{|c|c|c|c|c|c|c|}
\hline Country & $\begin{array}{c}\text { Present } \\
\text { study }\end{array}$ & India & England & $\begin{array}{l}\text { Nether- } \\
\text { lands }\end{array}$ & \multicolumn{2}{|c|}{$\begin{array}{c}\text { United States of } \\
\text { America }\end{array}$} \\
\hline Year & 1973 & 1968 & 1965 & 1965 & Nelson & Ed. 1969 \\
\hline & P 50 & P 50 & P 50 & P 50 & P 10 & P 50 \\
\hline $6 \mathrm{yr}$. & 17.71 & 16.3 & 20.5 & 21.2 & 18.55 & 21.91 \\
\hline $7 \mathrm{yr}$. & 18.50 & 18.0 & 22.6 & 23.6 & 20.77 & 24.54 \\
\hline $8 \mathrm{yr}$. & 19.53 & 19.7 & 25.0 & 26.2 & 23.22 & 27.26 \\
\hline 9 yr. & 21.97 & 21.5 & 27.5 & 28.8 & 25.54 & 29.94 \\
\hline $10 \mathrm{yr}$. & 23.23 & 23.5 & 30.3 & 31.4 & 27.71 & 32.61 \\
\hline $11 \mathrm{yr}$. & 24.91 & 25.9 & 33.6 & 34.5 & 30.07 & 35.20 \\
\hline $12 \mathrm{yr}$. & 27.09 & 28.5 & 37.7 & 37.9 & 32,66 & 38.28 \\
\hline $13 \mathrm{yr}$. & 29.51 & 32.1 & 42.6 & 42.2 & 34.97 & 42.18 \\
\hline $14 \mathrm{yr}$. & 32.39 & 35.7 & 48.8 & 47.8 & 39.55 & 48.81 \\
\hline
\end{tabular}


TABLE 9: Height of girls from different countries

\begin{tabular}{|c|c|c|c|c|c|c|}
\hline Country & $\begin{array}{l}\text { Present } \\
\text { study }\end{array}$ & India & England & $\begin{array}{l}\text { Nether- } \\
\text { lands }\end{array}$ & \multicolumn{2}{|c|}{$\begin{array}{c}\text { United States of } \\
\text { America }\end{array}$} \\
\hline Year & 1973 & 1968 & 1965 & 1965 & \multicolumn{2}{|c|}{ Nelson 9th Ed. 1969} \\
\hline & P 50 & P 50 & P 50 & P 50 & P 10 & P 50 \\
\hline $6 \mathrm{yr}$. & 108.34 & 1074 & 113.4 & 117.3 & 110.6 & 115.9 \\
\hline $7 \mathrm{yr}$. & 112.41 & 112.8 & 119.3 & 123.3 & 116.8 & 122.3 \\
\hline $8 \mathrm{yr}$. & 115.58 & 118.2 & 125.0 & 129.0 & 122.1 & 128.0 \\
\hline $9 \mathrm{yr}$. & 120.24 & 122.9 & 130.6 & 134.2 & 127.0 & 132.9 \\
\hline $10 \mathrm{yr}$. & 125.11 & 128.4 & 136.4 & 139.1 & 131.7 & 138.6 \\
\hline $11 \mathrm{yr}$. & 129.74 & 133.6 & 142.7 & 144.1 & 137.0 & 144.7 \\
\hline $12 \mathrm{yr}$. & 135.25 & 139.2 & 149.3 & 151.0 & 142.6 & 151.9 \\
\hline $13 \mathrm{yr}$. & 140.07 & 143.9 & 155.5 & 157.2 & 149.1 & 157.1 \\
\hline $14 \mathrm{yr}$. & 143.54 & 147.5 & 159.6 & 161.2 & 153.0 & 159.6 \\
\hline
\end{tabular}

TABLE 10: Weight of girls from different countries

\begin{tabular}{|c|c|c|c|c|c|c|}
\hline Country & $\begin{array}{l}\text { Present } \\
\text { study }\end{array}$ & India & England & $\begin{array}{l}\text { Nother- } \\
\text { lands }\end{array}$ & \multicolumn{2}{|c|}{$\begin{array}{c}\text { United States of } \\
\text { America }\end{array}$} \\
\hline \multirow[t]{2}{*}{ Year } & 1973 & 1968 & 1965 & 1965 & \multicolumn{2}{|c|}{ Nelson 9th Ed. 1969.} \\
\hline & P 50 & P 50 & P 50 & P 50 & P 10 & P 50 \\
\hline $6 \mathrm{yr}$ & 17.02 & 16.0 & 20.4 & 20.8 & 17.96 & 21.09 \\
\hline $7 \mathrm{yr}$. & 18.28 & 17.6 & 22.6 & 23.2 & 20.19 & 23.68 \\
\hline $8 \mathrm{yr}$. & 19.56 & 19.4 & 25.1 & 25.8 & 22.04 & 26.35 \\
\hline 9 уг. & 21.60 & 21.3 & 27.7 & 28.5 & 23.86 & 28.94 \\
\hline $10 \mathrm{yr}$. & 23.71 & 23.6 & 31.1 & 31.3 & 25.90 & 31.89 \\
\hline $11 \mathrm{yr}$. & 25.85 & 26.4 & 35.2 & 34.8 & 29.40 & 35.74 \\
\hline $12 \mathrm{yr}$. & 29.14 & 29.8 & 40.5 & 39.7 & 31.52 & 39.74 \\
\hline $13 \mathrm{yr}$. & 32.69 & 33.3 & 45.8 & 45.0 & 36.24 & 44.95 \\
\hline $14 \mathrm{yr}$. & 36.14 & 36.8 & 51.0 & 49.8 & 41.28 & 49.17 \\
\hline
\end{tabular}

same median values for height and weight. English children were somewhat lower. The median height of Indian children was about the same as found in this study but their height for children over 7 years of age showed a greater increment, so that at the age of 14 years the Indian girls were approximately 4 $\mathrm{cm}$. and boys $10 \mathrm{~cm}$. taller than the respective children in this study. Compared with the American standard, the boys in this study at the ages of 6 and 14 years were respectively 6 and $23 \mathrm{~cm}$. shorter and 4.2 and $16.4 \mathrm{~kg}$. lighter, while girls at the same ages were respectively 7.5 and $16 \mathrm{~cm}$. shorter and 4 and $13 \mathrm{~kg}$. lighter. As seen in graph 11 and 12 , the 90 th and 50 th percentiles of this study lie respectively far below the 50th and 10th percentiles of the American standard. These differences might be due to factors influencing growth such as race, climate, food, socio-economical conditions and methods of measurement.

It is said that the secular shift still continues even in developed countries.
Since improvement of health care in developing countries is progressing fastly, the relevancy of growth charts must be periodically revised.

This study cannot be compared with Zakaria's (1956) because he determined the age of the subjects by guessing while this study used the records from official birth certificates, also the study of Klerks (1953) cannot be taken for comparison because the number of this subjects was too small.

\section{Acknowledgement}

The authors wish to express their gratitude to Professor Howard V. Meredith (USA) and Dr. Steendijk (The Netherlands) for their valuable suggestions, to P.N. Kimia Farma for their partial sponsorship, to Ir. Toto Warsa from the Faculty of Agriculture, Padjadjaran University for carrying out the statistical analysis and to all other institutions for their valuable assistance during this survey.

\section{REFERENCES}

1. GOPALAN, $C$. and $K$. VIJAYA RA GHAVAN : Nutrition Atlas of India, National Institute of Nutrition Indian Council of Medical Research, Hyderabad, India, $146-153$ (1971).

2. GUNTHER : Uber der grenzen des biologischen Norm bereiches. Deutsche m.W Mrt. 1927, p. 396.

3. HUTH, A. : Die Bewertung von Körpermasze. Anthrop. Anzeiger, 1926, p. 33.

4. HARTAMAN T., HENDRA PERMADHI, AZHALI M.S. : Body weight and height of school children in Bandung. Paediatr. Indones. 13 : $293-301$ (1973). Nutritional Status of Indonesian school children. Berita Kementerian Kesehatan Republik Indonesia, 5 (4) : $11-51$ (1956). Descriptive and comparative study of body size on United States School Girls. Growth. $26: 283-295$ (1962).
5. KLERKS, J.V. : The assessment of the

6. MEREDITH, H.V. and KNOTT, V.B. : 
7. NELSON, W.E. : Textbook of Pediatrics, 9th Ed., 44 - 47 (Saunders, Philade]phia/London/Toronto 1969).

8. State University of Iowa, Height, Weight Interpretation Folder prepared for the Joint Committee of Health Problems in Education of the NEA and AMA. 1963 revision.

9. TANNER, J.M.; WHITEHOUSE, R.H. and TAKAISHI, M. : Standards from birth to maturity for height, weight, height velocity and weight velocity; $\mathrm{Bri}$ tish Children, 1965. Arch. Dis. Child. $41: 454-613$ (1966)

10. VAN WIERINGEN, J.C.; WAFELBAK KER, F.; VERBURGE, H.P.; DE HAAS, J.H. : Groeidiagrammen Nederland, 1965 (Wolters - Noordhoff, Groningen 1968).

11. ZAKARIA : Tinggi dan berat bada pemuda Indonesia. Maj. Kedok. Indones. $6: 353-369$ (1956)
CM

950

145

135

130

125

120

115

110

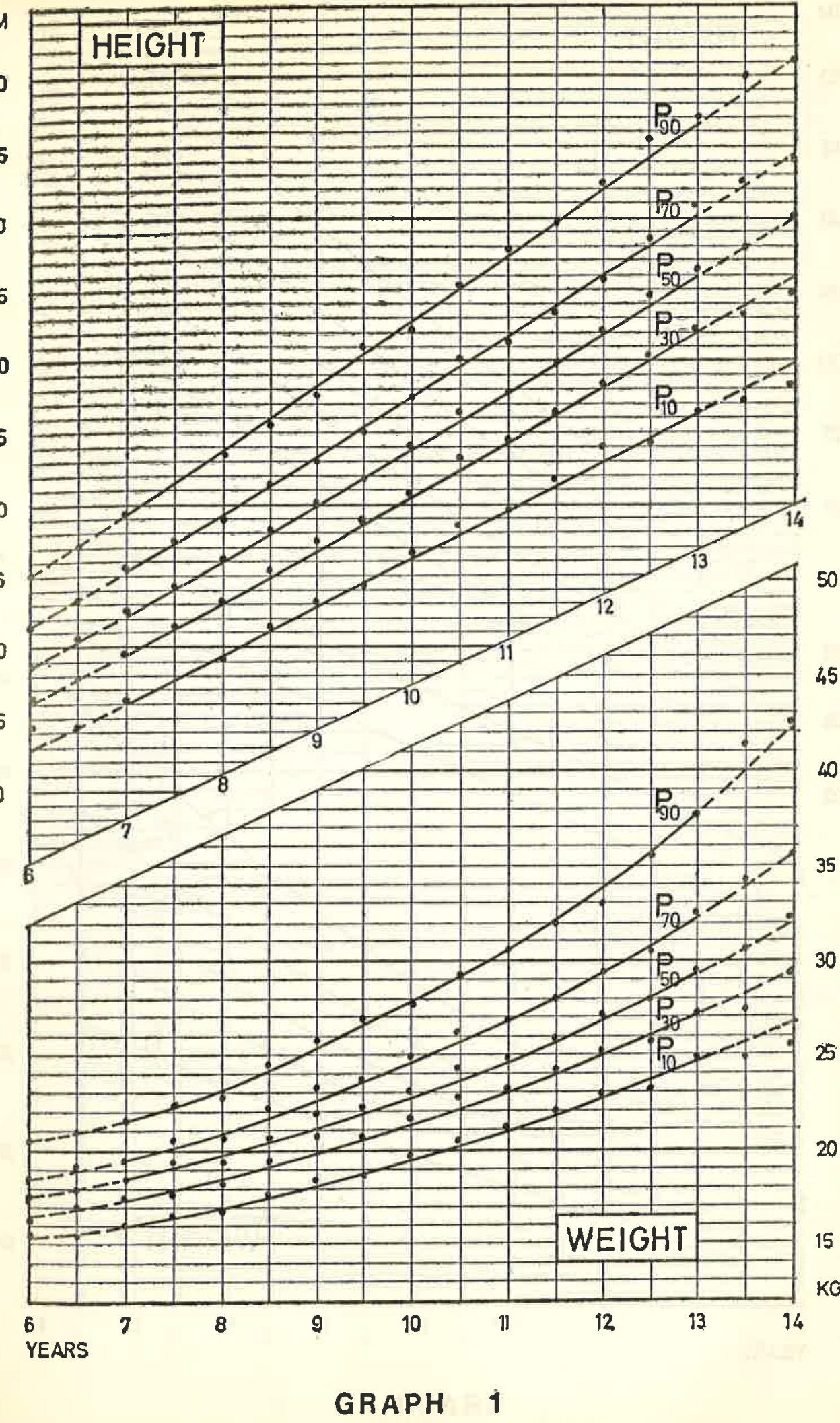



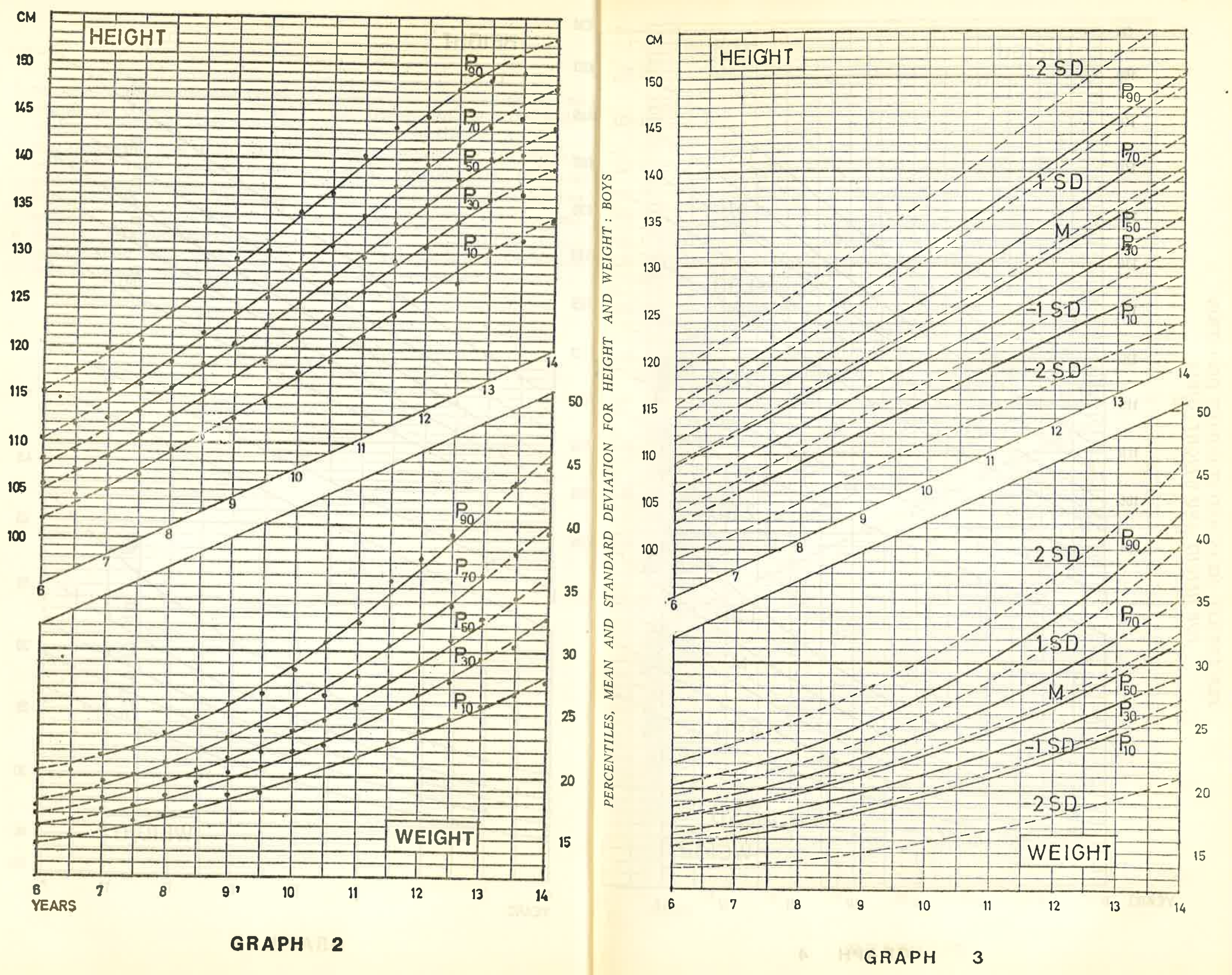


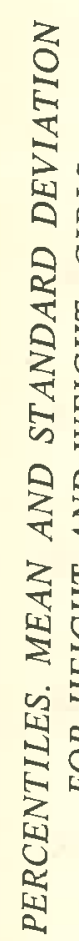
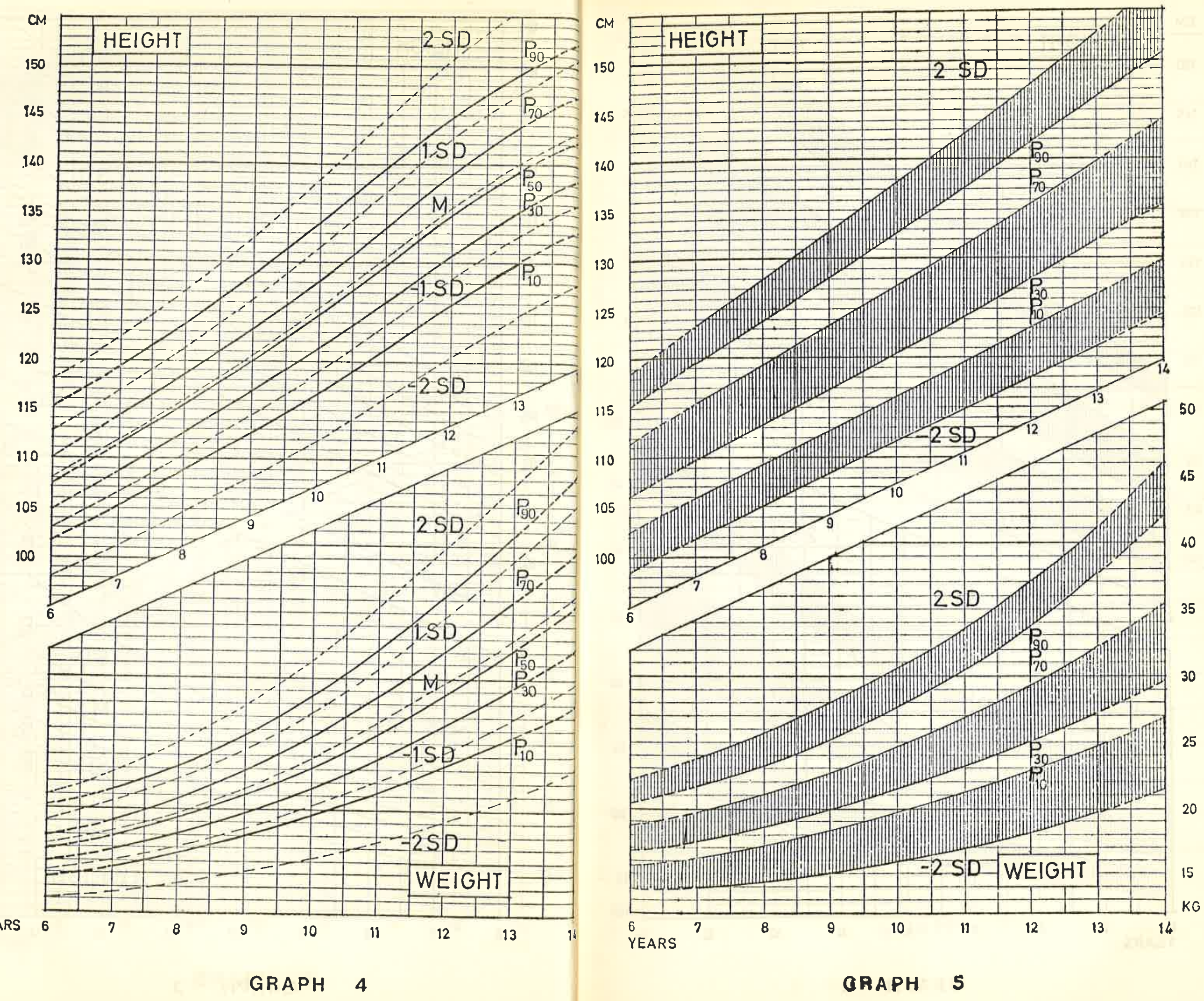

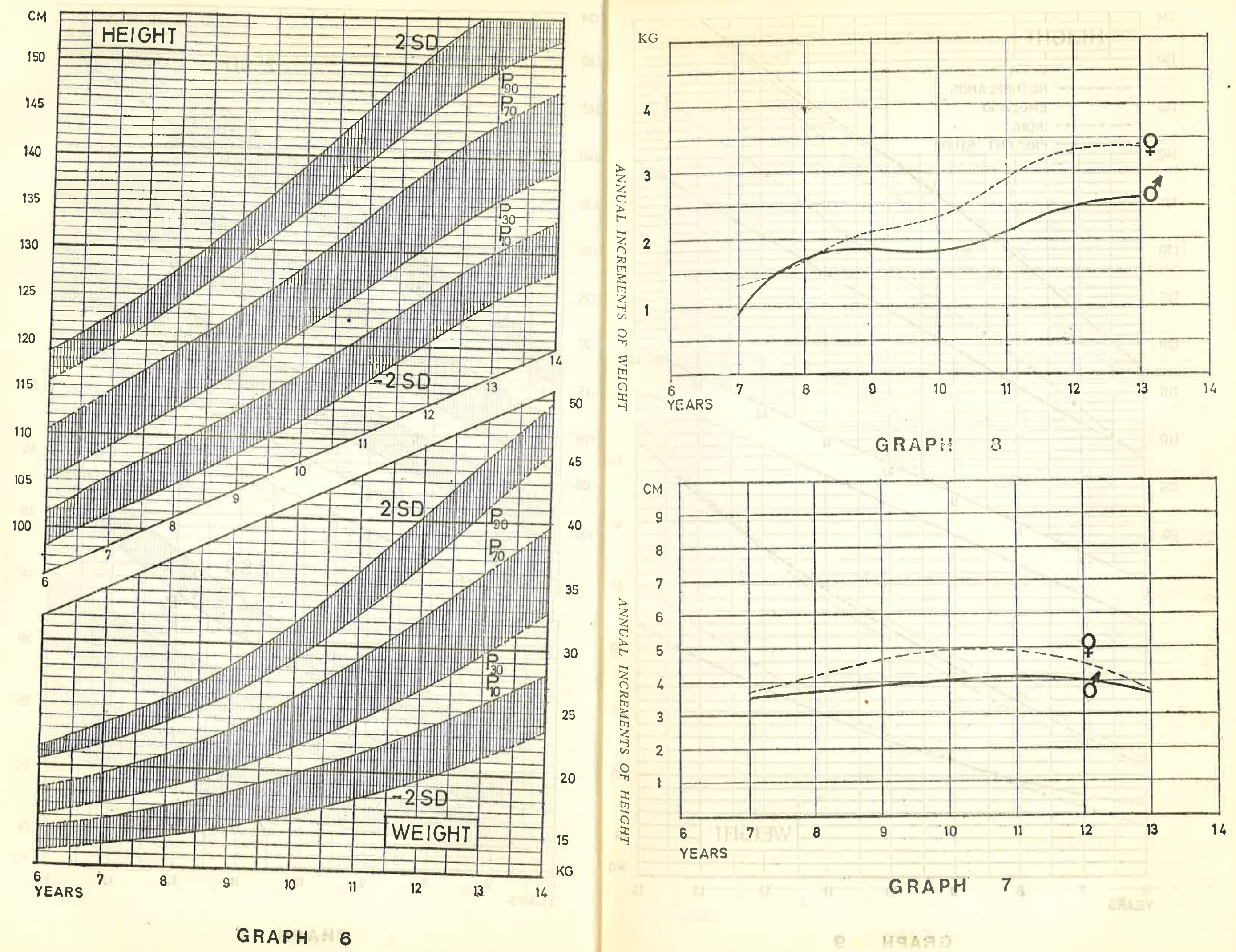

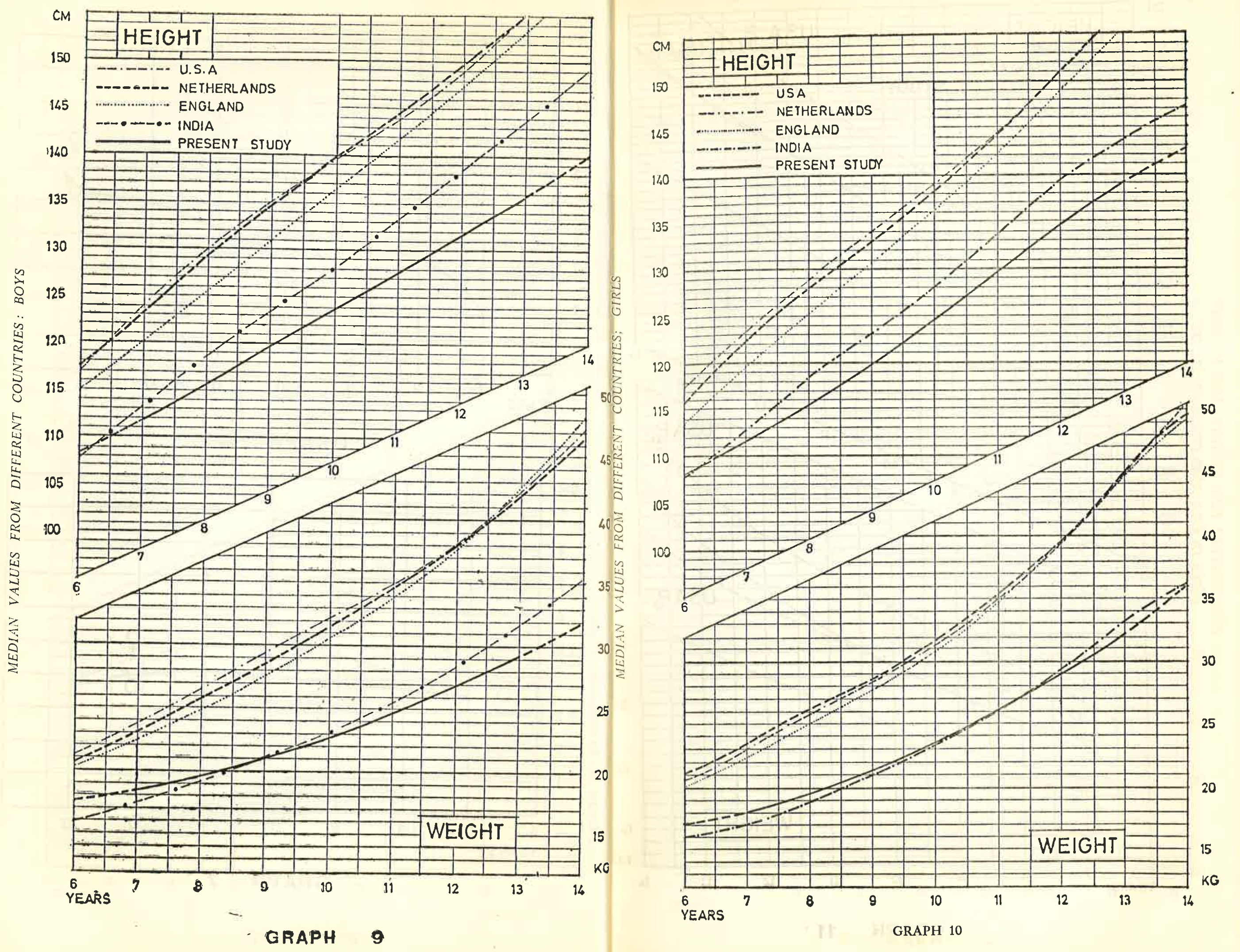
